\title{
JUAL BELI SECARA \\ ONLINE MENURUT PANDANGAN HUKUM ISLAM
}

\author{
Munir Salim \\ Fakultas Syariah dan Hukum Universitas Islam Negeri (UIN) Alauddin Makassar
}

\begin{abstract}
The use of modern technology (such as computers or mobile phones) as a tool to facilitate the business of buying and selling is one of the most profitable marketing strategy. In today's digital era there are many trade transactions through cyberspace (online or via internet), so that between seller and buyer is not limited by space and time. In the past, in the time of the invention of internet technology if someone intends to buy an item then he will come to the place where the goods are sold, the buyer can check directly the condition of the goods he wants then bargain between buyer and seller, if the agreement between the seller and buyer then the handover of money and goods takes place. The conventional buying process is set out in figh muamalah, which requires the existence of four things namely Sighat al'aqd (ijab qabul), Mahallul 'aqd (object of agreement/ goods), Al'aqidaian (the parties who carry out the contents of the agreement) and Maudhu' ul'aqd (the purpose of the agreement).

In sighat al'aqd (qabul ijab) is performed with spoken, written or gesture speech for those who are unable to speak or write. It can even be carried out with deeds (fi'li) which show the willingness of both parties to enter into an agreement (sale and purchase) commonly known as al mu'athah. Mahallul 'aqd requires that objects or goods that have been agreed upon are real, can be submitted when there is agreement and not goods that are prohibited according to syara'. Al'aqidaian are the parties that implement the contents of the agreement must meet the requirements such as aqil baligh, sensible, healthy, adult / not mumayyid and proficient law. While maudhu'ul 'aqd means that the goal made the agreement (sale and purchase) that the seller handed over goods or services while the buyer gave some money.
\end{abstract}

Keywords:

Buying and Selling Online, Halal, Haram

\section{Abstrak}

Penggunaan teknologi modern (seperti komputer atau telepon genggam) sebagai alat bantu guna memperlancar kegiatan usaha jual beli merupakan salah satu strategi pemasaran yang sangat menguntungkan. Di era digital sekarang ini terdapat banyak transaksi 
perdagangan melalui dunia maya (online atau via internet), sehingga antara penjual dan pembeli tidak dibatasi oleh ruang dan waktu.

Dahulu, pada masa belum ditemukannya teknologi internet apabila seseorang bermaksud membeli suatu barang maka ia akan mendatangi tempat dimana barang itu dijual, pembeli dapat memeriksa secara langsung kondisi barang yang ia inginkan kemudian terjadi tawar menawar antara pembeli dan penjual, apabila tercapai kesepakatan antara penjual dan pembeli barulah terjadi serah terima uang dan barang. Proses jual beli konvensional inilah yang diatur dalam fiqh muamalah, yang mensyaratkan adanya empat hal yaitu Sighat al'aqd (ijab qabul), Mahallul 'aqd (obyek perjanjian / barang), Al'aqidaian (para pihak yang melaksanakan isi perjanjian) dan Maudhu'ul'aqd (tujuan perjanjian).

Dalam sighat al'aqd (ijab qabul) dilaksanakan dengan ucapan lisan, tulisan atau isyarat bagi mereka yang tidak mampu berbicara atau menulis. Bahkan dapat dilaksanakan dengan perbuatan (fi'li) yang menunjukkan kerelaan kedua belah pihak untuk melakukan suatu perjanjian (jual beli) yang umumnya dikenal dengan al mu'athah. Mahallul 'aqd mensyaratkan obyek atau barang yang diperjanjikan sudah ada nyata, dapat diserahkan ketika terjadi kesepakatan serta bukan barang yang dilarang menurut syara'. Al'aqidaian adalah para pihak yang melaksanakan isi perjanjian haruslah memenuhi syarat seperti aqil baligh, berakal, sehat, dewasa/bukan mumayyid dan cakap hukum. Sedangkan maudhu'ul 'aqd berarti yang menjadi tujuan dibuatnya perjanjian (jual beli) yakni penjual menyerahkan barang atau jasa sedangkan pembeli menyerahkan sejumlah uang.

Kata kunci:

Jual beli online, Halal, Haram

\section{A. PENDAHULUAN}

B erdagang / berbisnis merupakan salah satu aktivitas yang sangat dianjurkan dalam ajaran Islam. Bahkan, Rasulullah SAW sendiri pun dalam salah satu hadistnya mengatakan bahwa 9 dari 10 pintu rezeki adalah melalui pintu berdagang. Artinya, melalui jalan perdagangan inilah, pintu-pintu rezeki akan dapat dibuka sehingga karunia Allah terpancar daripadanya. Jual beli merupakan sesuatu yang diperbolehkan (menurut QS 2: 275 yang dalam potongan artinya “...padahal Allah telah menghalalkan jual beli dan mengharamkan riba..."), dengan catatan selama dilakukan dengan benar sesuai dengan tuntunan ajaran Islam.

Dalil di atas dimaksudkan untuk transaksi offline. Sekarang bagaimana dengan transaksi online di akhir zaman ini? Kalau kita bicara tentang bisnis online, banyak sekali macam dan jenisnya. Namun demikian secara garis besar bisa di artikan 
sebagai jual beli barang dan jasa melalui media elektronik, khususnya melalui internet atau secara online.

Mungkin ada definisi lain untuk bisnis online, ada istilah e-commerce. Tetapi yang pasti, setiap kali orang berbicara tentang e-commerce, mereka memahaminya sebagai bisnis yang berhubungan dengan internet. Dari definisi diatas, bisa diketahui karakteristik bisnis online, yaitu: 1) Terjadinya transaksi antara dua belah pihak; 2) Adanya pertukaran barang, jasa, atau informasi; 3) Internet merupakan media utama dalam proses atau mekanisme akad tersebut.

Dari karakteristik di atas, bisa di lihat bahwa yang membedakan bisnis online dengan bisnis offline yaitu proses transaksi (akad) dan media utama dalam proses tersebut. Akad merupakan unsur penting dalam suatu bisnis. Secara umum, bisnis dalam Islam menjelaskan adanya transaksi yang bersifat fisik, dengan menghadirkan benda tersebut ketika transaksi, atau tanpa menghadirkan benda yang dipesan, tetapi dengan ketentuan harus dinyatakan sifat benda secara konkret, baik diserahkan langsung atau diserahkan kemudian sampai batas waktu tertentu, seperti dalam transaksi as-salam dan transaksi al-istishna. Transaksi as-salam merupakan bentuk transaksi dengan sistem pembayaran secara tunai/disegerakan tetapi penyerahan barang ditangguhkan. Sedang transaksi al-istishna merupakan bentuk transaksi dengan sistem pembayaran secara disegerakan atau secara ditangguhkan sesuai kesepakatan dan penyerahan barang yang ditangguhkan.

\section{B. PEMBAHASAN}

\section{Pengertian Jual Beli}

Secara bahasa, jual beli berarti penukaran secara mutlak. Secara terminologi, jual beli adalah saling menukar harta dengan harta dalam bentuk pemindahan milik dan pemilikan. Definisi di atas dapat dipahami bahwa inti dar jual beli adalah suatu perjanjian tukar menukar barang atau benda yang memiliki nilai, secara sukarela di antara kedua belah pihak, salah satu pihak menerima benda dan pihak lainnya menerima uang sebagai kompensasi barang, sesuai dengan perjanjian dan ketentuan yang telah dibenarkan syara dan disepakati. Islam mempertegas legalitas dan keabsahan jual-beli secara umum, serta menolak dan melarang konsep riba. Allah adalah dzat yang maha mengetahui atas hakikat persoalaan kehidupan, bahwa dalam suatu perkara terdapat kemaslahatan dan manfaat maka diperbolehkan. Sebaliknya, jika didalam terdapat kerusakan dan mudarat, maka Allah mencegah dan melarang untuk melakukannya.

\section{Landasan Hukum Jual Beli}

Berdasarkan Al-Quran Diantaranya:

\section{- Al-Baqarah ayat 275}

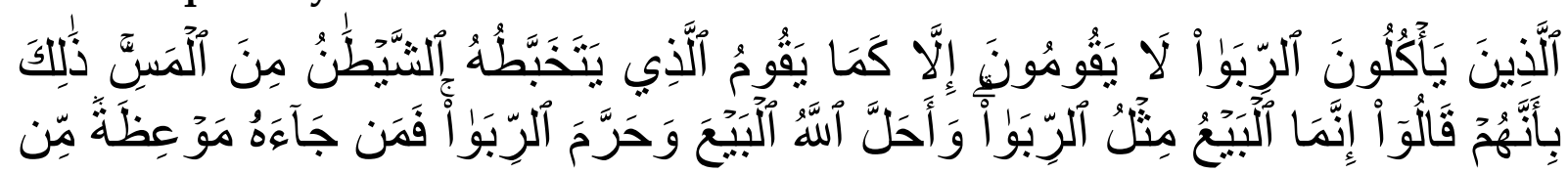




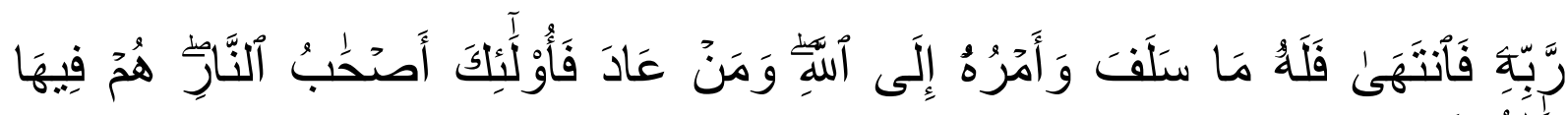

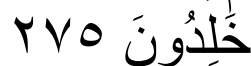

Artinya:

"Orang-orang yang makan (mengambil) riba tidak dapat berdiri melainkan seperti berdirinya orang yang kemasukan syaitan lantaran (tekanan) penyakit gila. Keadaan mereka yang demikian itu, adalah disebabkan mereka berkata (berpendapat), sesungguhnya jual beli itu sama dengan riba, padahal Allah telah menghalalkan jual beli dan mengharamkan riba. Orang-orang yang telah sampai kepadanya larangan dari Tuhannya, lalu terus berhenti (dari mengambil riba), maka baginya apa yang telah diambilnya dahulu (sebelum datang larangan); dan urusannya (terserah) kepada Allah. Orang yang kembali (mengambil riba), maka orang itu adalah penghuni-penghuni neraka; mereka kekal di dalamnya.

- An-Nisa ayat 5

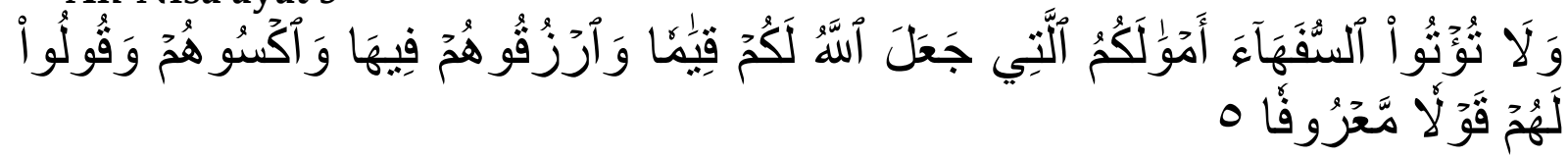

Artinya:

"Dan janganlah kamu serahkan kepada orang-orang yang belum sempurna akalnya, harta (mereka yang ada dalam kekuasaanmu) yang dijadikan Allah sebagai pokok kehidupan. Berilah mereka belanja dan pakaian (dari hasil harta itu) dan ucapkanlah kepada mereka katakata yang baik."

- An-Nisa ayat 29

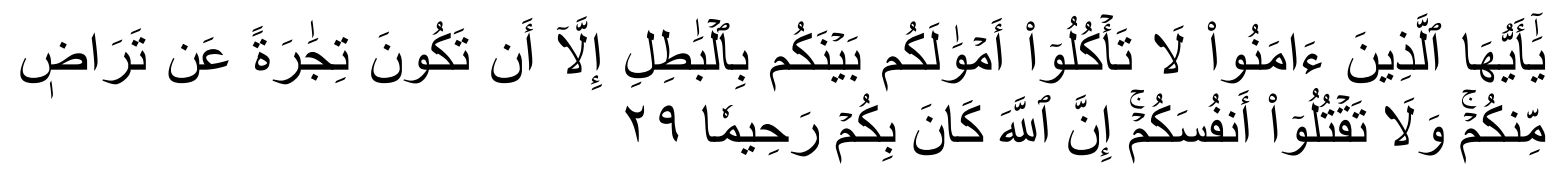

Artinya:

"Hai orang-orang yang beriman, janganlah kamu saling memakan harta sesamamu dengan jalan yang batil, kecuali dengan jalan perniagaan yang berlaku dengan suka sama-suka di antara kamu. Dan janganlah kamu membunuh dirimu; sesungguhnya Allah adalah Maha Penyayang kepadamu." 


\section{Berdasarkan Sunnah}

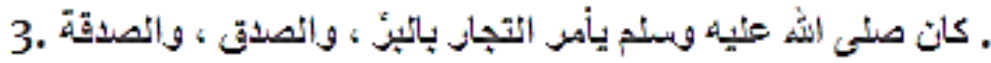

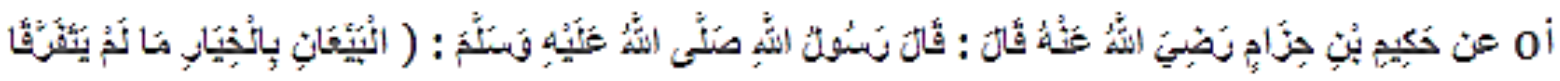

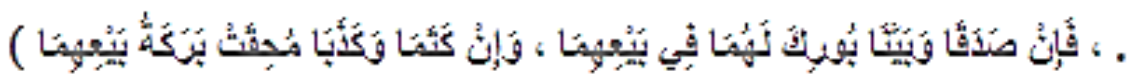

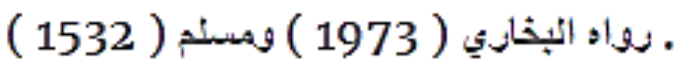

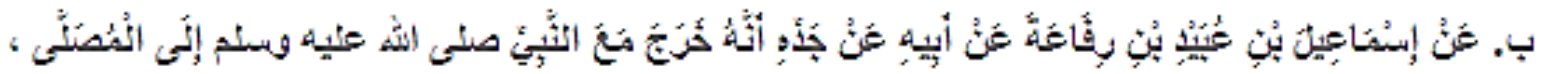

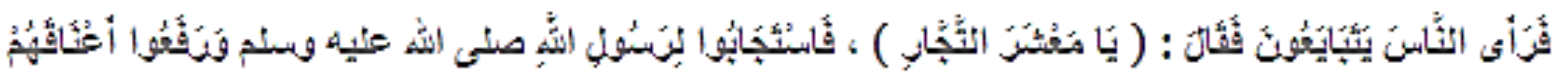

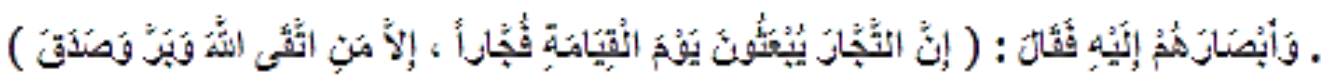

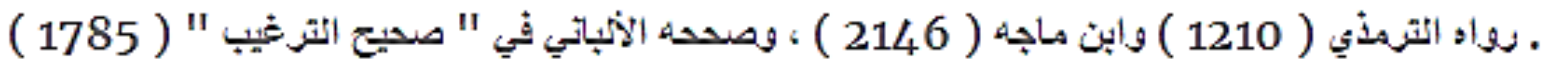

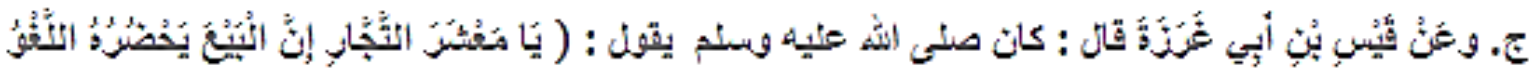

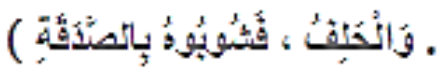

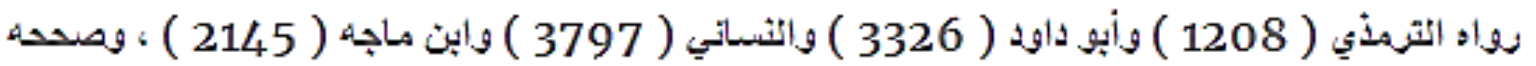

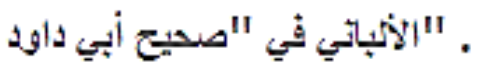

Rasulullah و سدلم عل يه الله صدلى berbuat baik, jujur dan bersedekah.

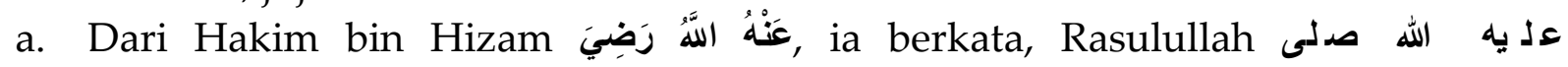
و سدلم transaksi atau membatalkannya) selama mereka belum berpisah. Jika keduanya jujur dan menjelaskan apa adanya, maka keduanya diberkahi dalam jual belinya. Jika keduanya menyembunyikan (cacat) dan berdusta, maka akan dihapuslah berkah pada keduanya." (HR. Bukhari no. 1973 dan Muslim no. 1532)

b. Dari Isma'il bin 'Ubaid bin Rifa'ah, dari bapaknya dari kakeknya, sesungguhnya ia keluar bersama Nabi و سدلم عل يه الله صدلى menuju mushalla, lalu beliau melihat orang-orang sedang berjual beli, maka beliau pun bersabda, "Wahai para pedagang," Maka mereka mendatangi Rasulullah ودلم على يه الله صدلى "Wan menengadahkan leher serta pandangan mereka. Lalu beliau bersabda, 
"Sesungguhnya para pedagang akan dibangkitkan di hari kiamat dalam keadaan durhaka, kecuali orang yang bertakwa kepada Allah, berbuat baik dan bersedakah." (HR. Tirmizi no. 1210, Ibnu Majah no. 2146, dishahihkan oleh AlAlbany dalam Shahih Targhib, no. 1785)

c. Dari Qais bin Abi Gharzah, dia berkata, "Rasulullah ودلم عل يه الله صدلىbersabda, "Wahai para pedagang, sesungguhnya dalam jual beli ada kelalaian dan sumpah, maka bersihkanlah dengan sedekah." (HR. Tirmizi no. 1208, Abu Daud, no. 3326, Nasai no. 3797, Ibnu Majah no. 2145. Dishahihkan oleh Al-Albany dalam Shahih Abu Daud).

\section{Berdasarkan Ijma}

Secara ijma', para ulama pun sepakat akan halalnya jual beli. Begitu pula berdasarkan qiyas. Manusia tentu amat butuh dengan jual beli. Ada ketergantungan antara manusia dan lainnya dalam hal memperoleh uang dan barang. Tidak mungkin hal itu diberi cuma-cuma melainkan dengan timbal balik. Oleh karena itu berdasarkan hikmah, jual beli itu dibolehkan untuk mencapai hal yang dimaksud.

Hukum asal jual beli itu hal, namun bisa keluar dari hukum asal jika terdapat pelanggaran-pelanggaran syari' at. Sehingga dikenal ada jual beli yang terlarang.

\section{Rukun dan Pelaksanaan Jual Beli}

Jual beli mempunyai rukun dan syarat yang harus dipenuhi, sehingga jual beli itu dapat dikatakan sah oleh syara'. Ada perbedaan pendapat mengenai rukun jual beli, menurut ulama Hanafiyah rukun jual beli hanya satu, yaitu ijab (ungkapan membeli dari pembeli) dan qabul (ungkapan menjual dan menjual). Mereka berpendapat seperti ini, karena menurut mereka rukun dalam jual beli itu hanyalah kerelaan antara penjual dan pembeli, akan tetapi karena unsur kerelaan itu merupakan unsur hati yang sulit untuk diindera sehingga tidak kelihatan, maka diperlukan indikator yang menunjukkan kerelaan tersebut dari kedua belah pihak dapat dalam bentuk perkataan, yaitu ijab dan qabul atau dalam bentuk perbuatan, yaitu saling memberi (penyerahan barang dan penerimaan uang). Sedangkan Jumhur Ulama' berpendapat bahwa rukun jual beli ada empat, yaitu:

- Orang yang berakad atau al-muta'aqidain (penjual dan pembeli)

- Sigat (lafal ijab dan qabul)

- Ma'qud 'alaih (barang yang dibeli)

- Nilai tukar pengganti barang

Menurut ulama Hanafiyah, orang yang berakad, barang yang dibeli, dan nilai tukar barang termasuk ke dalam syarat-syarat jual beli, bukan rukun jual beli.

\section{Syarat Jual Beli}

Berikut beberapa syarat sah jual beli yang dirangkum dari kitab Taudhihul ahkam 4/213-214, Fiqih Ekonomi Keuangan Islam dan beberapa referensi lainnya untuk diketahui dan direalisasikan dalam praktek jual beli agar tidak terjerumus ke dalam praktek perniagaan yang menyimpang. 
Pertama, persyaratan yang berkaitan dengan pelaku praktek jual beli, baik penjual maupun pembeli, yaitu:

- Hendaknya kedua belah pihak melakukan jual beli dengan ridha dan sukarela, tanpa ada paksaan. Sesuai dengan kalam Allah ta'ala dalam QS. An-Nisaa': 29.

- Kedua belah pihak berkompeten dalam melakukan praktek jual beli, yakni dia adalah seorang mukallaf dan rasyid (memiliki kemampuan dalam mengatur uang), sehingga tidak sah transaksi yang dilakukan oleh anak kecil yang tidak cakap, orang gila atau orang yang dipaksa. Hal ini merupakan salah satu bukti keadilan agama ini yang berupaya melindungi hak milik manusia dari kezaliman, karena seseorang yang gila, safiih (tidak cakap dalam bertransaksi) atau orang yang dipaksa, tidak mampu untuk membedakan transaksi mana yang baik dan buruk bagi dirinya sehingga dirinya rentan dirugikan dalam transaksi yang dilakukannya.

Kedua, yang berkaitan dengan objek/barang yang diperjualbelikan, syaratsyaratnya yaitu:

- Objek jual beli (baik berupa barang jualan atau harganya/uang) merupakan barang yang suci dan bermanfaat, bukan barang najis atau barang yang haram, karena barang yang secara dzatnya haram terlarang untuk diperjualbelikan.

- Objek jual beli merupakan hak milik penuh, seseorang bisa menjual barang yang bukan miliknya apabila mendapat izin dari pemilik barang. Rasulullah shallallahu 'alaihi wa sallam bersabda,

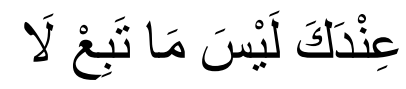

"Janganlah engkau menjual barang yang bukan milikmu." (HR. Abu Dawud 3503, Tirmidzi 1232, An Nasaa'i VII/289, Ibnu Majah 2187, Ahmad III/402 dan 434; dishahihkan Syaikh Salim bin 'Ied Al Hilaly)

Seseorang diperbolehkan melakukan transaksi terhadap barang yang bukan miliknya dengan syarat pemilik memberi izin atau rida terhadap apa yang dilakukannya, karena yang menjadi tolok ukur dalam perkara muamalah adalah rida pemilik. (Lihat Figh wa Fatawal Buyu' hal. 24). Hal ini ditunjukkan oleh persetujuan Nabi shallallahu 'alaihi wa sallam terhadap perbuatan Urwah tatkala beliau memerintahkannya untuk membeli kambing buat beliau. (HR. Bukhari bab 28 nomor 3642)

- $\quad$ Objek jual beli dapat diserahterimakan, sehingga tidak sah menjual burung yang terbang di udara, menjual unta atau sejenisnya yang kabur dari kandang dan semisalnya. Transaksi yang mengandung objek jual beli seperti ini diharamkan karena mengandung gharar (spekulasi) dan menjual barang yang tidak dapat diserahkan.

- $\quad$ Objek jual beli dan jumlah pembayarannya diketahui secara jelas oleh kedua belah pihak sehingga terhindar dari gharar. Abu Hurairah berkata: "Rasulullah shallallahu 'alaihi wa sallam melarang jual beli hashaath (jual beli dengan 
menggunakan kerikil yang dilemparkan untuk menentukan barang yang akan dijual) dan jual beli gharar." (HR. Muslim: 1513)

Selain itu, tidak diperkenankan seseorang menyembunyikan cacat/aib suatu barang ketika melakukan jual beli. Rasulullah shallallahu 'alaihi wa sallam bersabda:

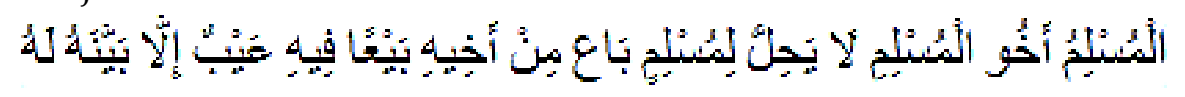

"Seorang muslim adalah saudara bagi muslim yang lain. Tidak halal bagi seorang muslim menjual barang dagangan yang memiliki cacat kepada saudaranya sesama muslim, melainkan ia harus menjelaskan cacat itu kepadanya" (HR. Ibnu Majah nomor 2246, Ahmad IV/158, Hakim II/8, Baihaqi V/320; dishahihkan Syaikh Salim bin ‘Ied Al Hilali)

Beliau shallallahu 'alaihi wa sallam juga bersabda:

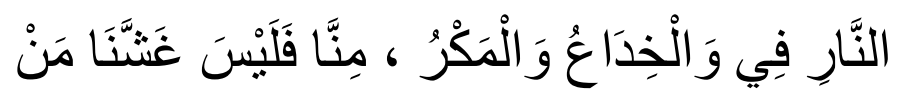

"Barang siapa yang berlaku curang terhadap kami, maka ia bukan dari golongan kami. Perbuatan makar dan tipu daya tempatnya di neraka" (HR. Ibnu Hibban 567, Thabrani dalam Mu'jamul Kabiir 10234, Abu Nu'aim dalam Al Hilyah IV/189; dihasankan Syaikh Salim Al Hilaly)

\section{HUKUM JUAL BELI SECARA ONLINE}

Para Ulama sepakat bahwa transaksi yang disyaratkan tunai serah terima barang dan uang tidak dibenarkan untuk dilakukan secara telepon atau internet (online), seperti jual beli emas dan perak karena ini termasuk riba nasi'ah. Kecuali objek yang diperjualbelikan dapat diserahterimakan pada saat itu juga, seperti penukaran uang asing melalui ATM maka hukumnya boleh karena penukaran uang rupiah dengan Dollar harganya sesuai dengan kurs pada hari itu.

Untuk barang yang tidak disyaratkan serah terima tunai dalam jual belinya, yaitu seluruh jenis barang, kecuali emas dan perak dan mata uang maka jual beli melalui internet (jual beli online), dapat ditakhrij dengan jual beli melalui surat menyurat. Adapun jual beli melalu telepon dan internet merupakan jual beli langsung dalam akad ijab dan qabul.

Sebagaimana diputuskan oleh Majma' Al Fiqh Al Islami (Divisi Fiqih OKI) keputusan no. 52 (3/6) tahun 1990, yang berbunyi "Apabila akad terjadi antara dua orang yang berjauhan tidak berada dalam satu majlis dan pelaku transaksi, satu dengan lainnya tidak saling melihat, tidak saling mendengar rekan transaksinya, dan media antara mereka adalah tulisan atau surat atau orang suruhan, hal ini dapat diterapkan pada faksimili, teleks, dan layar komputer (internet). Maka akad berlangsung dengan sampainya ijab dan qabul kepada masing-masing pihak yang bertransaksi. Bila transaksi berlangsung dalam satu waktu sedangkan kedua belah pihak berada di tempat yang berjauhan, hal ini dapat diterapkan pada transaksi melalui telepon ataupun telepon seluler, maka ijab dan qabul yang terjadi adalah langsung seolah-olah keduanya berada dalam satu tempat." 
Dalam transaksi mengunakan internet, penyediaan aplikasi permohonan barang oleh pihak penjual di website merupakan ijab dan pengisian serta pengiriman aplikasi yang telah diisi oleh pembeli merupakan qabul. Adapun barang hanya dapat dilihat gambarnya serta dijelaskan spesifikasinya dengan gamblang dan lengkap, dengan penjelasan yang dapat mempengaruhi harga jual barang.

Setelah ijab qabul, pihak penjual meminta pembeli melakukan tranfer uang ke rekening bank milik penjual. Setelah uang diterima, si penjual baru mengirim barangnya melalui kurir atau jasa pengiriman barang.

Jadi, Transaksi seperti ini (jual beli online) mayoritas para Ulama menghalalkannya selama tidak ada unsur gharar atau ketidakjelasan, dengan memberikan spesifikasi baik berupa gambar, jenis, warna, bentuk, model dan yang mempengaruhi harga barang.

\section{- Pemilik Situs Merupakan Wakil (Agen) Dari Pemilik Barang}

Apabila pemilik situs / website adalah orang yang bukan pemilik barang namun sudah membuat kesepakatan dengan pemilik barang agar dia diberi kepercayaan untuk menjualkan barangnya dengan mendapatkan komisi persentase yang sudah disepakati bersama, maka hal inipun diperbolehkan karena hakikatnya wakil hukumnya sama dengan pemilik barang.

Sebagaimana riwayat Jabir Bin Abdullah r.a. ia berkata, "Aku hendak pergi menuju Khaibar, lalu aku mendatangi Rasulullah SAW, aku mengucapkan salam kepadanya sambil menyampaikan bahwa aku akan pergi ke Khaibar, maka Nabi Muhammad SAW bersabda, "Bila engkau mendataangi wakilku di Khaibar ambillah darinya 15 wasq Kurma, Bila dia meminta bukti (bahwa engkau adalah wakilku) maka letakkanlah tanganmu ti atas tulang bawah lehernya" (HR Abu Daud. Menurut Ibnu Hajar sanad hadits ini Hasan).

\section{- Pemilik Situs Bukan Pemilik Barang}

Pada kasus ini seorang pembeli menghubungi penjual barang dengan mengirim aplikasi yang sesungguhnya tanpa melakukan akad jual beli, hanya sebatas konfirmasi keberadaan barang, setelah meyakini keberadaan barang, lalu si penjual meminta pembeli mentransfer uang ke rekeningnya. Setelah uang ia terima barulah ia membeli barang tersebut dan mengirimkannya kepada pembeli.

Apabila pemilik situs menampilkan barang tapi bukan pemilik barang tersebut, maka para Ulama sepakat bahwa tidak sah hukum jual belinya karena mengandung unsur gharar disebabkan pada saat akad berlangsung penjual belum dapat memastikan apakah barang dapat ia kirimkan atau tidak.

Sebagaimana sabda Nabi shallallahu 'alaihi wa sallam yang diriwayatkan oleh Hakim bin Hizam, ia berkata, "Wahai Rasulullah, seseorang datang kepadaku untuk membeli suatu barang, kebetulan barang tersebut sedang tidak kumiliki, apakah boleh aku menjualnya kemudian aku membeli barang yang diinginkannya dari pasar? Maka Nabi 
SAW menjawab, "Jangan engkau jual barang yang belum engkau miliki." (HR. Abu Daud).

\section{Solusi Syar'i}

Supaya jual beli online seperti ini ingin menjadi sah, maka pemilik situs dapat melakukan langkah-langkah berikut:

1. Beritahu bahwa setiap calon pembeli bahwa penyediaan aplikasi permohonan barang bukan berarti ijab dari penjual (pemilik situs)

2. Setelah calon pembeli mengisi aplikasi dan mengirimkannya, pemilik situs tidak boleh langsung akad jual beli melainkan harus membeli dulu barang dari pemilik barang sesungguhnya dan ia terima barangnya. Kemudian baru ia menjawab permohonan pembeli dan memintanya mentransfer uang ke rekening miliknya lalu barang dikirim kepada pembeli dengan jaminan barang sesuai dengan di gambar dan spesifikasinya. Untuk menghindari kerugian akibat pembeli via jual beli online menarik kembali keinginan atau membatalkan jual belinya, maka si pemilik situs membuat perjanjian selama waktu tunggu ( 3 hari) ia berhak mengembalikan barang kepada pemilik barang yang sesungguhnya.

\section{Macam-Macam Jual Beli}

Jual beli ditinjau dari segi hukumnya dibagi menjadi dua macam yaitu:

1. Jual beli yang syah menurut hukum dan batal menurut hukum

2. Dari segi obyek jual beli dan segi pelaku jual beli

Ditinjau dari segi benda yang yang dijadikan obyek jual beli dapat dikemukakan pendapat imam Taqiyuddin bahwa jual beli dibagai menjadi tiga bentuk:

1. jual beli benda yang kelihatan

Maksudnya adalah pada wajtu melakukan akad jual beli benda atau barang yang diperjualbelikan ada didepan penjual dan pembeli, seperti membeli beras dipasar dan boleh dilakukan.

2. Jual beli yang disebutkan sifat-sifatnya dalam janji

Sama dengan jual beli salam (pesanan), ataupun yang dilakukan secara tidak tunai (kontan). Maksudnya ialah perjanjian sesuatu yang penyarahan barangbarangnya ditangguhkan hingga masa tertentu.

Dalam salam berlaku semua syarat jual beli dan syarat-syarat tambahannya ialah:

1. Ketika melakukan akad salam disebutkan sifat-sifatnya yang mungkin dijangkau oleh pembeli, baik berupa barang yang dapat ditakar, ditimbang maupun diukur. Dalam akad harus disebutkan segala sesuatu yang bias mempertinggi dan memperendah harga barang itu.

2. Barang yang akan diserahkan hendaknya barang-barang yang biasa didapat dipasar.

3. Harga hendaknya dipegang ditempat akad berlangsug. 
Jual Beli yang dilarang dan batal hukumnya adalah:

1. Barang yang dihukumkan najis oleh agama seperti anjing, babi, berhala, bangkai dan khamar.

2. Jual beli sperma (mani) hewan, seperti mengawinkan seekor domba jantan dengan betina agar dapat memperoleh keturunan, jual beli ini haram hukumnya karena Rasulullah SAW bersabda yang artinya: Dari Ibn Umar ra berkata: Rasulullah SAW telah melarang menjual mani binatang. (HR. Bukhari)

3. Jual beli anak binatang yang masih berada dalam perut induknya.

4. Jual beli dengan mukhadharah yaitu menjual buah-buahan yang belum pantas untuk dipanen.

5. Jual beli dengan munabadzah yaitu jual beli secara lempar-melempar.

6. Jual beli gharar yaitu jual beli yang samar sehingga kemungkinan adanya penipuan, contoh: penjualan ikan yang masih dikolam.

7. Larangan menjual makanan sehingga dua kali ditakar, hal ini menunjukkan kurang saling mempercayainya antara penjual dan pembeli.

\section{JUAL BELI DENGAN AKAD SALAM SECARA ONLINE (E-COMMERCE)}

Secara bahasa, transaksi (akad) digunakan berbagai banyak arti, yang hanya secara keseluruhan kembali pada bentuk ikatan atau hubungan terhadap dua hal yaitu As-Salam atau disebut juga As-Salaf. Kedua itu merupakan istilah dalam bahasa arab yang mengandung makna "penyerahan". Sedangkan para fuqaha" menyebutnya dengan al-Mahawij (barang-barang mendesak) karena ia sejenis jual beli barang yang tidak ada di tempat, sementara dua pokok yang melakukan transaksi jual beli mendesak.

Jual beli pesanan dalam fiqih Islam disebut as-salam menurut bahasa penduduk hijaz, sedangkan bahasa penduduk iraq as-salaf. Kedua kata ini mempunyai makna yang sama, sebagaimana dua kata tersebut digunakan oleh Nabi, sebagaimana diriwayatkan bahwa Rasulullah ketika membicarakan akad bay'salam, beliau menggunakan kata as-salaf disamping as-salam, sehingga dua kata tersebut merupakan kata yang sinonim. Secara terminologi ulama" fiqh mendefinisikannya:

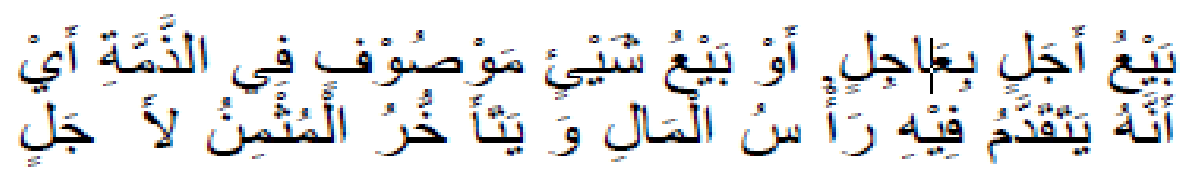

Artinya:

"menjual suatu barang yang penyerahannya ditunda, atau menjual suatu barang yang ciricirinya jelas dengan pembayaran modal di awal, sedangkan barangnya diserahkan kemudian hari"

Dengan adanya pendapat di atas sudah cukup untuk memberikan perwakilan penjelasan dari akad tersebut, di mana inti dari pendapat tersebut adalah bahwa akad salam merupakan akad pesanan dengan membayar terlebih dahulu dan barangnya 
diserahkan kemudian, tapi ciri-ciri barang tersebut haruslah jelas penyifatannya. Masih banyak lagi pendapat yang diungkapkan para pemikir dalam masalah ini, sebagaimana al-Qurthuby, An-Nawawi dan ulamaee malikiyah, serta yang lain, mereka ikut andil memberikan sumbangsih pemikiran dalam masalah ini, akan tetapi karena pendapatnya hampir sama dengan pandapat yang diungkapkan diatas, maka penulis berfikir bahwa pendapat diatas sudah cukup untuk mewakilinya.

Dalam Islam dituntut untuk lebih jelas dalam memberikan suatu landasan hukum, maka dari itu Islam melampirkan sebuah dasar hukum yang terlampir dalam al-Qur'an, al-Hadits ataupun Ijma'. Perlu diketahui sebelumnya mengenai transaksi ini secara khusus dalam al qur an tidak ada yang selama ini dijadikan landasan hukum adalah transaksi jual beli secara global, karena bay' salam termasuk salah satu jual beli dalam bentuk khusus. Maka hadist Nabi dan ijma' ulama 'e banyak menjelaskannya dan tentunya $A l-Q u r^{\prime} a n$ yang membicarakan secara global sudah mencakup atas diperbolehkannya jual beli akad salam. Adapun landasan hukum Islam mengenai hal tersebut adalah:

1. Ayat tentang bay as-salam:

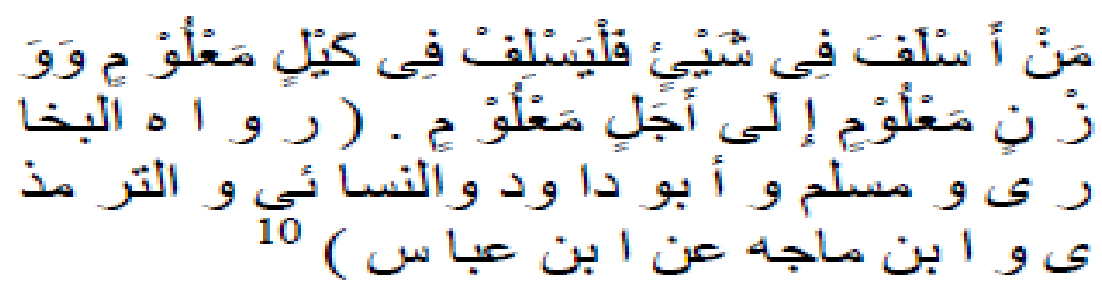

Artinya:

"Jika kamu melakukan jual beli salam, maka lakukanlah dalam ukuran tertentu, timbangan tertentu, dan waktu tertentu (HR Bukhari, Muslim, Abu Daud, An-Nasa ${ }^{\mathrm{ee}} \mathrm{i}$ at Tirmizi dan Ibn Majah dari Ibnu 'Abbas).

2. Hukum tentang bay as-salam:

Adapun hadits tentang dasar hukum diperbolehkannya transaksi ini adalah sebagaimana riwayat Hakim bin Hizam:

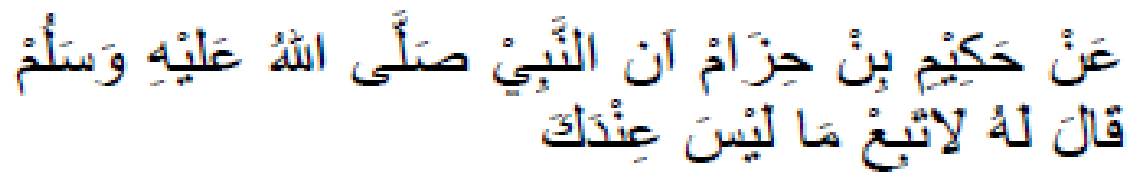

Artinya:

"dari hakim bin hizam, sesungguhnya Nabi bersabda: janganlah menjual sesuatu yang tidak ada padamu

3. Rahasia salam

Orang yang mempunyai perusahaan sering membutuhkan uang untuk keperluan perusahaan mereka, bahkan sewaktu-waktu kegiatan perusahaannya sampai terhambat karena kekurangan bahan pokok. Sedangkan si pembeli, selain akan mendapat barang yang sesuai dengan yang diinginkannya, ia pun sudah 
menolong kemajuan perusahaannya. Maka untuk kepentingan tersebut Allah mengadakan peraturan salam.

4. Rukun salam

- Ada si penjual dan si pembeli

- Ada barang dan uang

- Ada sigat (lafad akad)

5. Syarat-syarat salam

- Uangya hendaklah dibayar di tempat akad, berarti pembayaran dilakukan lebih dulu.

- Barangnya menjadi utang bagi si penjual

- Barangnya dapat diberikan sesuai waktu yang dijanjikan berarti pada waktu yang dijanjikan barang itu harus sudah ada.

- Barang tersebut hendaklah jelas ukurannya, baik takaran, timbangan, ukuran, ataupun bilangannya, menurut kebiasaan cara menjual barang semacam itu.

- Diketahui dan disebutkan sifat-sifat barangnya. Dengan sifat itu, berarti harga dan kemauan orang pada barang tersebut dapat berbeda. Sifat-sifat ini hendaknya jelas sehingga tidak ada keraguan yang akan mengakibatkan perselisihan nanti antara pembeli kedua belah pihak (sipenjual dan sipembeli). Begitu juga macamnya, harus pula disebutkan, misalnya daging kambing, daging sapi, atau daging kerbau.

- Disebutkan tempat menerimanya, kalau tempat akad tidak layak buat menerima barang tersebut. Akad salam meski terus, berarti tidak ada khiyar syarat.

Menurut Syafiei, Hanafi, dan Maliki dibolehkan barang yang dijual secara salam diberikan segera atau ditangguhkan. Sedangkan pendapat Hambali tidak dibolehkan penyerahan barang dengan segera, dan tentu saja harus ada penangguhan, meskipun beberapa hari.

\section{E. TINJAUAN HUKUM ISLAM TERHADAP JUAL BELI SECARA ONLINE}

Sebagaimana keterangan dan penjelasan mengenai dasar hokum hingga persyaratan transaksi salam dalam hokum islam, kalo dilihat secara sepintas mungkin mengarah pada ketidak dibolehkannya transaksi secara online (Ecommerce), disebabkan ketidak jelasan tempat dan tidak hadirnya kedua pihak yang terlibat dalam tempat.

Tapi kalo kita coba lebih telaah lagi dengan mencoba mengkolaborasikan antara ungkapan al-Qur'an, hadits dan ijmma', dengan sebuah landasan: "Pada awalnya semua Muamalah diperbolehkan sehingga ada dalil yang menunjukkan keharamannya"

Sebagaimana ungkapan Abdullah bin Mas'ud : Bahwa apa yang telah dipandang baik oleh muslim maka baiklah dihadapan Allah, akan tetapi sebaliknya. 
Dan yang paling penting adalah kejujuran, keadilan, dan kejelasan dengan memberikan data secara lengkap, dan tidak ada niatan untuk menipu atau merugikan orang lain, sebagaimana firman Allah dalam surat Albaqarah ayat 275 dan 282.

Langkah-langkah yang dapat kita tempuh agar jual beli secara online diperbolehkan, halal, dan sah menurut syariat islam:

a. Produk Halal. Kewajiban menjaga hukum halal-haram dalam objek perniagaan tetap berlaku, termasuk dalam perniagaan secara online, mengingat Islam mengharamkan hasil perniagaan barang atau layanan jasa yang haram, sebagaimana ditegaskan dalam hadis: "Sesungguhnya bila Allah telah mengharamkan atas suatu kaum untuk memakan sesuatu, pasti Ia mengharamkan pula hasil penjualannya." (HR Ahmad, dan lainnya). Boleh jadi ketika berniaga secara online, rasa sungkan atau segan kepada orang lain sirna atau berkurang. Tapi Anda pasti menyadari bahwa Allah 'Azza wa Jalla tetap mencatat halal atau haram perniagaan Anda.

b. Kejelasan Status. Di antara poin penting yang harus Anda perhatikan dalam setiap perniagaan adalah kejelasan status Anda. Apakah sebagai pemilik, atau paling kurang sebagai perwakilan dari pemilik barang, sehingga berwenang menjual barang. Ataukah Anda hanya menawaran jasa pengadaan barang, dan atas jasa ini Anda mensyaratkan imbalan tertentu. Ataukah sekadar seorang pedagang yang tidak memiliki barang namun bisa mendatangkan barang yang Anda tawarkan.

c. Kesesuaian Harga Dengan Kualitas Barang. Dalam jual beli online, kerap kali kita jumpai banyak pembeli merasa kecewa setelah melihat pakaian yang telah dibeli secara online. Entah itu kualitas kainnya, ataukah ukurang yang ternyata tidak pas dengan badan. Sebelum hal ini terjadi kembali pada Anda, patutnya anda mempertimbangkan benar apakah harga yang ditawarkan telah sesuai dengan kualitas barang yang akan dibeli. Sebaiknya juga Anda meminta foto real dari keadaan barang yang akan dijual.

d. Kejujuran Anda. Berniaga secara online, walaupun memiliki banyak keunggulan dan kemudahan, namun bukan berarti tanpa masalah. Berbagai masalah dapat saja muncul pada perniagaan secara online. Terutama masalah yang berkaitan dengan tingkat amanah kedua belah pihak.

Bisa jadi ada orang yang melakukan pembelian atau pemesanan. Namun setelah barang Anda kirim kepadanya, ia tidak melakukan pembayaran atau tidak melunasi sisa pembayarannya. Bila Anda sebagai pembeli, bisa jadi setelah Anda melakukan pembayaran, atau paling kurang mengirim uang muka, ternyata penjual berkhianat, dan tidak mengirimkan barang. Bisa jadi barang yang dikirim ternyata tidak sesuai dengan apa yang ia gambarkan di situsnya atau tidak sesuai dengan yang Anda inginkan. 


\section{F. PENUTUP}

\section{Kesimpulan}

Berbisnis melalui online satu sisi dapat memberi kemudahan dan menguntungkan bagi masyarakat. Namun kemudahan dan keuntungan itu jika tidak diiringi dengan etika budaya dan hukum yang tegas akan mudah terjebak dalam tipu muslihat, saling mencurangi dan saling menzalimi. Disinilah Islam bertujuan untuk melindungi umat manusia sampai kapanpun agar adanya aturan-aturan hukum jual beli dalam Islam yang sesuai dengan ketentuan syari'at agar tidak terjebak dengan keserakahan dan kezaliman yang meraja lela. Transaksi bisnis lewat online jika sesuai dengan aturan-aturan yang telah disebut di atas akan membawa kemajuan bagi masyarakat dan negara.

Sebagaima telah disebutkan di atas, hukum asal mu'amalah adalah al-ibaahah (boleh) selama tidak ada dalil yang melarangnya. Namun demikian, bukan berarti tidak ada rambu-rambu yang mengaturnya. Transaksi online diperbolehkan menurut Islam selama tidak mengandung unsur-unsur yang dapat merusaknya seperti riba, kezhaliman, penipuan, kecurangan dan yang sejenisnya serta memenuhi rukunrukun dan syarat-syarat didalam jual belinya. Transaksi online dibolehkan menurut Islam berdasarkan prinsip-prinsip yang ada dalam perdagangan menurut Islam, khususnya dianalogikan dengan prinsip transaksi as-salam, kecuali pada barang/jasa yang tidak boleh untuk diperdagangkan sesuai syariat Islam.

\section{Saran}

Berbisnis online bagi para pebisnis yang melaksanakannya harusnya mengetahui syarat sah yang diperbolehkan dalam Islam. Tidak boleh menjual yang diharamkan dan menipu pembeli.

\section{Daftar Pustaka}

Al-Qur'an dan Terjemahan

Anggraeni, Kusuma Sily. 2012. Jual - Beli Menurut Agama Islam.

Asnawi, Haris Faulidi. 2008. Transaksi Bisnis E-Commerce Perspektif Islam. Yogyakarta: Laskar Press.

Al-mwardi dalam Manshur ibnu Idris al-Bahiti, Kasaf al-Qur'an, hlm. 288

Daud, Ali Mahmud. 1993. Hukum Islam Di Indonesia: Pengantar Hukum Islam Dan

Tata Hokum Islam Di Indonesia. Jakarta: PT: Grafindo

Hidayat, Enang. 2015. Fiqih Jual Beli. Bandung: PT. Remaja Rosdakarya. 
Ibn Abidin, Ad-Dar Al-Muhtar, Hasan, Ali, Bebagai Macam Transaksi Dalam Islam, Basyit, Ahmad Azhar, Asas-asa Hukum Mu'amalah. (Yogyakarta: UII pres, 1990),

Ihsan, Ghufron, M.A. 2008. Fiqh Muamalah. Jakarta: Prenada Media Grup

Lubis Ibrahim. 1995. Ekonomi Islam Suatu Pengantar. Jakarta: PT. Kalam Mulia.

Mannan Abdul. Hukum Ekonomi Syari'ah dalam Perspektif Kewenangan Peradilan Agama.

Mardani DR. 2015. Hukum Sistem Ekonomi Islam di Indonesia. Bandung: PT. Aditama.

Suhartono, 2010. Perniagaan online Syariah: suatu Kajian dalam prespektif Hukum perikatan Islam. Jurnal Muqtasid (Jurnal Ekonomi dan Perbankan Syari'ah)

Suhrawardi Lubis. 2000. Hukum Ekonomi Islam. Jakarta: Sinar Grafika Offset.

Sunarto, Andi. 2009. Seluk Beluk E-Commerce. Yogyakarta: Gaya Ilmu.

Tho'in, Muhammad. 2016. Larangan Riba Dalam Teks dan Konteks (Studi Atas Hadits Riwayat Muslim Tentang Pelaknatan Riba. Jurnal Ilmiah Ekonomi Islam, LPPM STIE AAS Surakarta. Vol. 2 No. 2, Juli 63-72. 